\title{
Symbolic consumption and representation of self: a study of interactions in a virtual community of Ubuntu-Br users
}

\author{
OSÍRIS Luís da CUNHA FERNANDES ${ }^{1}$ \\ Nelson da Cruz MONTEIRO Fernandes ${ }^{2}$ \\ FERNANDO GOMES DE PAIVA JÚNIOR ${ }^{3}$ \\ ANDRÉ LUIZ MARANHÃO dE SOUZA LEÃO ${ }^{3}$ \\ MARCONI FREITAS DA COSTA ${ }^{2}$
}

\author{
1 Instituto de TeCnologia de Pernambuco (ITEP), RECIFE - PE, BRAZIL \\ 2 Universidade Federal de Pernambuco (UFPE) / Núcleo de Gestão, Caruaru - PE, Brazil \\ ${ }^{3}$ Universidade Federal de Pernambuco (UFPE) / Departamento de ClênCias Administrativas, ReCife - PE, BraziL
}

\begin{abstract}
This study aims to explain how the symbolic consumption of the Ubuntu operating system is used for the representation of self in interactions in the Ubuntu virtual community from Brazil. We adopted the Goffmanian concept of self, the netnography of communication as the research method, and case study as a research strategy. The paralinguistic, the extralinguistic, and the definition of "I" are aspects used in virtual interactions. They have the linguistic function of corroborating and praising the statements of migration of Windows users to Ubuntu, emphasizing the distinctive features of the concept of Ubuntu, highlighting its expression of shared feelings of love and freedom, as ways of projecting the self of humanity to each other. In the case of the operating system, this characteristic is represented through the provision of support among users at the forum of the virtual community.
\end{abstract}

Keywords: Symbolic Consumption. Self. Netnography of Communication. Virtual Communities. Ubuntu.

\section{Consumo simbólico e representação do self: um estudo de interações em uma comunidade virtual de usuários} Ubuntu-Br

\section{Resumo}

Este estudo tem como objetivo explicar como o consumo simbólico do sistema operacional Ubuntu é utilizado para a representação do self em interações na comunidade virtual Ubuntu do Brasil. Adotamos a concepção Goffmaniana do self, a netnografia da comunicação como método de pesquisa e o estudo de caso como estratégia de pesquisa. O paralinguístic, o extralinguístico e a definição do "eu" são aspectos usados nas interações virtuais. Eles têm a função linguística de corroborar e elogiar as declarações de migração de usuários do Windows para o Ubuntu, enfatizando as características distintivas do Ubuntu, destacando a expressão de sentimentos compartilhados de amor e liberdade, como formas de projetar o self de humanidade entre si. No caso do sistema operacional, essa característica é representada através da provisão de suporte entre usuários no fórum da comunidade virtual.

Palavras-chave: Consumo Simbólico. Self. Netnografia da Comunicação. Comunidades Virtuais. Ubuntu.

\section{El consumo simbólico y la representación del self: un estudio de las interacciones en una comunidad virtual de usuarios Ubuntu-Br}

\section{Resumen}

Este estudio tiene como objetivo explicar cómo el consumo simbólico del sistema operativo Ubuntu es utilizado para la representación del self en interacciones en la comunidad virtual Ubuntu de Brasil. Adoptamos la concepción goffmaniana del self, la netnografía de la comunicación como método de investigación y el estudio de caso como estrategia de investigación. El paralingüístico, el extralingüístico y la definición del self son aspectos usados en las interacciones virtuales. Ellos tienen la función lingüística de corroborar y elogiar las declaraciones de migración de usuarios de Windows a Ubuntu, enfatizando las características distintivas de Ubuntu, destacando la expresión de sentimientos compartidos de amor y libertad como formas de proyectar el self de humanidad entre sí. En el caso del sistema operativo, esta característica se representa a través de la provisión de soporte entre usuarios en el foro de la comunidad virtual.

Palabras clave: Consumo simbólico. Self. Netnografía de la comunicación. Comunidades virtuales. Ubuntu. 
Symbolic consumption and representation of self: a study of interactions in a virtual community of Ubuntu-Br users
Osíris Luís da Cunha Fernandes | Nelson da Cruz Monteiro Fernandes Fernando Gomes de Paiva Júnior | André Luiz Maranhão de Souza Leão Marconi Freitas da Costa

\section{INTRODUCTION}

The integration of information in global networks has caused the overcoming of the nation-state in this time marked by globalization, especially in economic, cultural and political areas (GUAN, WANG, JIN et al., 2018). On the other hand, capitalism transformed by informationalism and the constant surveillance via the web (HIMANEN, 2001; MCCAHILL, 2002) are two of the most striking characteristics of this time and have hindered the control of the economic activities within national boundaries (MORGAN, 2001).

In this context, consumption activities permeate the interaction between people (CHAN and LI, 2010), and they no longer require physical presence as this can occur virtually or digitally (CASTELLS, 2002; HABIBI, LAROCHE and RICHARD, 2016),. Likewise, goods are used as a reference value of an ideal; they represent a meaning attributed to material and symbolic objects (SCHOUTEN, 1991; BANISTER, 2004). In other words, individuals no longer buy products or services only regarding their functionalities, but also in pursuit of the symbolic value to which they want to be associated (RAVASI and RINDOVA, 2008).

In a case of online consumption, much of the value related to the function or use of a product becomes invisible (WITT, 2010), since the perception of this value appears tied to symbolic elements associated with it (LUNA-CORTES, 2017). Therefore, the acts of buying and consumption also represent proactive efforts of consumer positioning in the social relations system (SCHAU and GILLY, 2003), considering that the change of artifacts' characteristics leads to them being used as symbolic representations to the extent that they reflect, express, and reconstitute the consumers' system of social relations (HAMMERL, DORNER, FOSCHT et al., 2016).

Thus, when we search the symbolic consumption of the Linux-based Operating System (OS) called Ubuntu, we cannot analyze it considering only the functional features, but fundamentally, the meanings it can articulate. So, in this study, we embrace the theoretical perspective of Sociolinguistic Interaction (GUMPERZ, 1999) that prioritizes the contextual analysis, and allows to access the Ubuntu virtual community inter-agents as potential sources of communication and whose actions and intentions of meaning, verbal, and nonverbal behaviors we intend to understand in their immediate context. The sociolinguistic allows us to investigate the use of language by the members of this community, realizing the connection between the paralinguistic and social aspects of their process of communication (GUMPERZ, 1982; SAVILLE-TROIKE, 2003).

In this study, we deal with the symbolic representation using the concept of self as developed in Erwin Goffman's (1990) social theory, whose roots lie in the symbolic interactionism as a way of getting closer to the understanding of the representation of self in online interactions through the symbolic consumption of Ubuntu Operating System. The study aims to answer the following research question: how does the representation of self in virtual interactions occur through the symbolic consumption of the Ubuntu Operating System?

\section{The Virtual Community of Ubuntu Users}

The history of the Ubuntu operating system must be told within the broader spectrum of the free software movement in Brazil and the world, and its antagonism with other logics of production and consumption of software (LOWE, POW, SERBAN et al., 2017), such as the Microsoft system and other corporate models.

In Brazil, Ubuntu-BR is the materialization of this movement and follows the same logic adopted in other countries. The Brazilian initiative uses the worldwide Ubuntu Manifesto as a foundation for users to enjoy the software free of charge, freely translated into Portuguese and with the possibility of adapting the code to be inclusive to people with disabilities.

Ubuntu reveals its alignment with the philosophy of free software by relying on four basic concepts of freedom: use, copying, modification, and redistribution (SILVEIRA, 2004). The user can legally use the Ubuntu operating system, make changes and adaptation, as well as make copies and redistribute information for free. These concepts allow knowledge accumulation through welcoming contributions made by any user.

To ensure that these four "principles of freedom" were maintained, the creator of the free software concept, Stallman (2002), designed the General Public License. This license aims to prevent the introduction of barriers to the use of free software, as long as the basic precepts of creation are maintained (SODERGERG, 2012). Also, the fact that the operating system is a software, and therefore, immaterial, allows it to be consumed simultaneously by several people. According to Lessig (2005), 
Symbolic consumption and representation of self: a study of interactions in a virtual community of Ubuntu-Br users
Osíris Luís da Cunha Fernandes | Nelson da Cruz Monteiro Fernandes Fernando Gomes de Paiva Júnior | André Luiz Maranhão de Souza Leão Marconi Freitas da Costa

this requirement of non-rivalry and non-exclusivity, typical of intangible goods, allows information, culture, and knowledge not to have exclusive ownership to satisfy the desire to create and learn. In this context, the history of free software and Ubuntu are deeply rooted in the participation of effective communities. The creation of a GNU/Linux distribution by Ubuntu represents the effort to create an ecosystem model with people interacting as a community.

Ubuntu is not the first Linux-based operating system to be released, but it was the first to bring features to the regular user, such as automatic installation of programs, office packages (Word, Excel and Power Point programs from Microsoft), as well as other system configuration facilities (VELLOZO, 2012). As a Free/Libre and Open Source Software (FLOSS), Ubuntu is formed by a dedicated group of hundreds of people working to produce a new release every six months. The system is the result of a network running from Debian operating system to thousands of large and small projects that produce code and documentation.

In addition, Ubuntu recognizes the contributions of various individuals - enthusiasts, artists, forum moderators, IRC channel operators, community event organizers, writers, translators, bug reporters and classifications persons - whatever the particular talent or interest. From this, Ubuntu has changed the universe of operating systems and the FLOSS by becoming a complete system for millions of desktop computers and servers. Thousands more of these users give back to the Ubuntu community by creating documentation, translating and programming.

To maintain a satisfactory flow of contributions to the brand, Ubuntu works to balance the importance of Canonicals' role in employing some individuals in the community. The project is based on a fundamental belief that software is built, supported and maintained only through strong relationships between individuals using the brand. Thus, by encouraging and supporting this community, the Ubuntu operating system achieves greater gains than the model that values only paid development.

For Hill and Bacon (2008), the project interactors believe that Canonical Ltd. was the main catalyst for the process that built Ubuntu, and the community of users was responsible for the successful distribution. Moreover, leading project leaders believe that the brand's success will only continue to grow through an alliance - in constant expansion - with these communityconforming users.

\section{Productive Consumption}

The consumption context addressed is based on the concept of "prosumer," which is based on the combination of the meanings of producer and consumer (TOFFLER, 1980). Pieske and Prado (2012) acknowledge that the consumer producing its products and services is not exactly new (grocery shopping, "do it yourself" fashion, self-help movements, and associations, self-service restaurants).

The discussion about this practice begins with a challenge by Kotler (1986) regarding the validity and extension of Toffler's (1980) thesis, of the existence of a new modality of consumption. Prosumers engage directly and indirectly in the creation and sharing of solutions in the production of goods and services, reinforcing the culture of active participation that is in opposition to the logic of the alienated-passive consumer (RITZER, 2015). The prosumer phenomenon occurred both in the pre-modern era and the modern era (IZVERCIANU, SERAN and BRANEA, 2014), and nowadays the contribution of information and communication technologies (ICTs) to networks, which enabled the productive abilities of these agents, the means for the distribution, capture, recovery and organization of specific productive processes.

In the context of Web 2.0, the prosumer is qualified as willful and does not seek profit, even when the efforts result in products or processes (RITZER and JUGERSON, 2010; RITZER, 2014). In the context of Web 2.0 technologies, goods and services reach to new markets is enhanced by the virtual interactions of prosumers (VAN DIJCK, 2009; ALMEIDA, MAZZON, MULLER NETO et al., 2012).

This prosumer's behavior means a form of empowerment, enabling the consumer as a political force and agent of transformation (CEVASCO, 2008). The prosumer consumption forms a space for the reproduction of market forces, and a place of production of meaning. Thus, it can be a place of struggle that is not restricted to the ownership of objects, since the emphasis is on their use, which is what gives the objects a social form.

Some contemporary works continue to refer to Kotler's seminal work, highlighting its importance. These studies, however, do not show significant theoretical advances and present a predominance of the debate around concepts and the managerial/ 
Symbolic consumption and representation of self: a study of interactions in a virtual community of Ubuntu-Br users
Osíris Luís da Cunha Fernandes | Nelson da Cruz Monteiro Fernandes Fernando Gomes de Paiva Júnior | André Luiz Maranhão de Souza Leão Marconi Freitas da Costa

utilitarian approach. Fonseca, Gonçalves, Oliveira et al. (2008) approach the prosumer as a "new user" who produces and consumes the products and services they "need," weaving a profile of a super individual with "new skills." This condition allows the prosumer to differentiate from the "ordinary" consumer that is outside the reality of web 2.0. Such an approach raises a historical reading without exploring the broader cultural transformations and forces that dictate the direction of the market (COMOR, 2011).

\section{Symbolic Consumption}

The behaviorists use the term symbolic consumption to describe acts of buying and consuming products for social and selfexpression, defined as the communication of social and individual identity (RAVASI and RINDOVA, 2008; DEANS, THOMAS, DAUBE et al., 2016). More recently, changes in cultural values and consumption patterns make us rethink the role of objects in the lives of people in affluent societies (TANGSUPWATTANA and LIU, 2017). Thus, in its production, the objects have undergone reformulation in form, appearance, color, style, and feeling, changing the way consumers experience and the associations they evoke (SHANG, CHEN and HUANG, 2012).

In this perspective, the objects are no longer seen only as functional tools and are now valued by the set of identity-related to the identity attributed to them in a particular cultural context (PRONAY and HETESI, 2016). That is, the objects shall be purchased and used not only by their ability to perform specific functions, but rather, for their meanings and the desire to possess them to show others. The objects serve, in this way, to the purpose of ratifying the status and the individual or collective identity (RAVASI and RINDONA, 2008; GBADAMOSI, 2015).

The changes in consumption patterns and cultural values promoted the emergence of new expectations and objectives around the role of technology goods in people's lives (HAMARI and KERONEN, 2017). The goods are symbols, whose possession and use reflect, express and reconstitute the system of social relationships and their perceived place (EKINCI, SIRAKAYA-TURK and PRECIADO, 2013). Such changes, however, have a direct impact on issues related to identity (SCHOUTEN, 1991), understood as the process of constructing meaning based on a cultural attribute, or a set of interrelated cultural attributes that prevails over other sources of meaning (CASTELLS, 2010).

\section{Notions of Self in Erving Goffman's Social Theory}

In his studies, Goffman (1990) explores the particularities of individual and social identity and the relations in a microsociological sphere group, through observing social interaction in everyday actions and directing their attention to how each person plays their role and manages the impression they make on others in different contexts. To do this, social interaction relies on a theatrical metaphor of social life, according to which the role played by a social actor (person) is established in response to the interpretation of other actors in scene (context), to the audience of potential participants, and the impression that the actor intends to portray (MUELLER, 2017).

For Blumer (1986), the term 'symbolic interaction' refers to the peculiar and distinctive nature of the interaction between humans. The peculiarity consists in the fact that human beings interpret or define each other's actions rather than merely react (DIONYSIOU and TSOUKAS, 2013). Thus, human interaction is mediated by the use and interpretation of symbols or by determining the significance of each on reaction (KOTARBA, 2014).

In the symbolic interactionist approach, people should interpret the meaning of things, events, and actions that are not originated in the relationship with the world but emerge from social interaction (HAMMERL, DORNER, FOSCHT et al., 2016). Therefore, from this perspective, symbols and their meanings play an essential role in forming the self, since they are only human and social elements, although they may arise from the relationship between these components, as well as modify and be modified by them in this regard (GRUBB and GRATHWOHL, 1967; BAUMHAMMER, SILVA and COSTA, 2017). This means that there is no passive relationship between the individual and society (MCCRACKEN, 1990). Figure 1 presents a summary of the main features of symbolic interactionism approach.

Theories of self that make up the symbolic interactionist tradition are originated from James' conception (1980), which differentiates "discriminated aspects" of the self, having them designated as I and Me (GECAS, 1982). For him, no aspect can be analyzed appropriately without the other been considered (HARMON-KIZER, KUMAR, ORTINAU et al., 2013). That is why the "I" corresponds to the 'pure' aspect of the self, to the 'subject,' to a sense of personal identity. 
Symbolic consumption and representation of self: a study of interactions in a virtual community of Ubuntu-Br users
Osíris Luís da Cunha Fernandes | Nelson da Cruz Monteiro Fernandes Fernando Gomes de Paiva Júnior | André Luiz Maranhão de Souza Leão Marconi Freitas da Costa

Figure 1

Main characteristics of symbolic interactionism

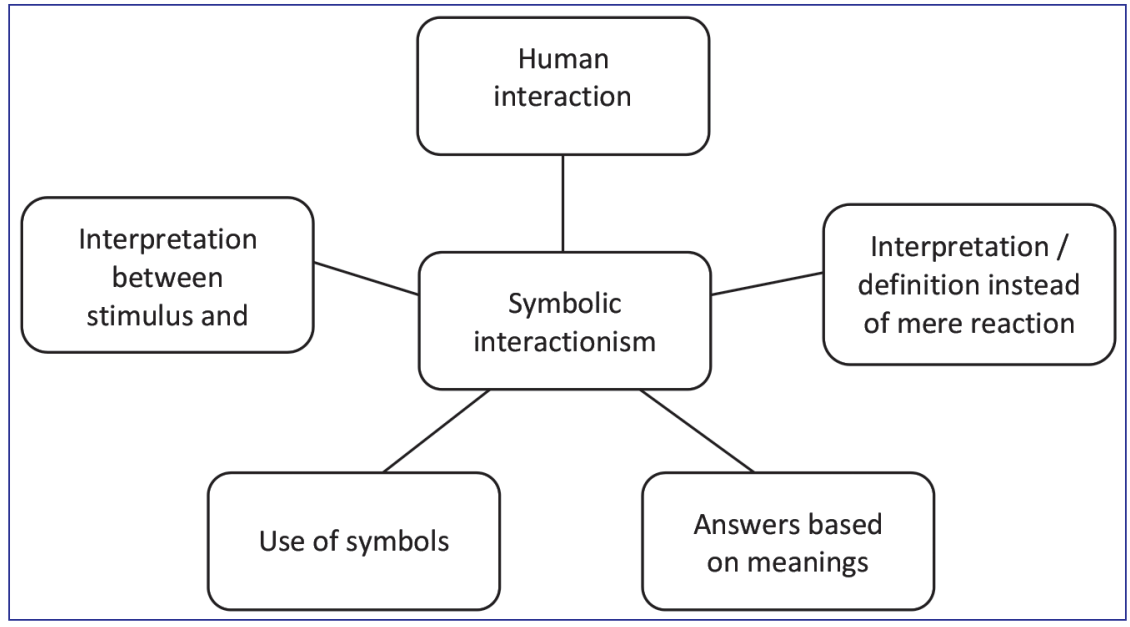

Source: Elaborated by the authors.

Goffman's symbolic-interactionist perspective reflects his quest to understand social microstructures through interaction. For Mead (2015), society is a communication tissue in which people, through interaction, influence each other, which makes self and society mutually constituted through language. This understanding of language is established in its practical effect, in which meaning always comes from its contexts of use, a notion theorized initially by Wittgenstein (2003). Thus, according to Habermas (2002), it is because social interactions function as language games that it is possible to have a simultaneous development between the constitution of self and the social structure.

Wittgenstein's concept of language game succeeds in translating well the multiplicity of practices and pragmatic changes aimed at persuading social actors to broaden the scope of their commitments to others and the tactics used in building inclusive communities such as the Ubuntu Users Virtual Community. According to Goffman (1990), this confirms the thesis that the human is socially constructed from their otherness. That is, their identity is built from interaction with peers, each in their social role, aiming to know themselves and others in interaction.

Moreover, the language games used in sewing these networks are made by unspoken rules that require existing intersubjective agreements in society before any process can work. This is because, according to Wittgenstein (2003), sewing agreements does not depend only on rules, there has to be agreement on how they are used. Understanding through language is not only a concordance in definitions but also (as strange as it may seem) a concordance in judgments (WITTGENSTEIN, 2003).

For Wittgenstein, "obeying a rule" is a practice, and our understanding of rules consists of the mastery of a technique. Thus, Wittgenstein understands rules as practices, inseparable from a specific way of life. According to Goffman (1990), communities help build the "I," which is based on the roles expressed in these collaborative environments, impregnated with the intermediary symbols of communication and language, verbal and nonverbal, as well as the conception of themselves through alterity (GOFFMAN, 1990).

\section{METHOD-ANALYTICAL PROCEDURES}

This research is in line with the conceptual principles of interactional sociolinguistics, which embodies the comprehension of the self-constitution through social interactions, providing a frame to understanding how individuals behave in such interactions (GOFFMAN, 1974; GUMPERZ, 1972). For the sake of epistemological consistency, it is aligned with the pragmatic perspective of language, whose design allows to understand that the meaning of signs can vary depending on how the signs are used, leading to the same term that assumes different meanings and even some new ones over time (WITTGENSTEIN, 2003). Therefore, this study falls within the interpretive tradition that understands the language as the basis for the construction of reality (GUMPERZ and HYMES, 1972), from a symbolic interactionist perspective (BLUMER, 1986). 
Symbolic consumption and representation of self: a study of interactions in a virtual community of Ubuntu-Br users
Osíris Luís da Cunha Fernandes | Nelson da Cruz Monteiro Fernandes Fernando Gomes de Paiva Júnior | André Luiz Maranhão de Souza Leão Marconi Freitas da Costa

When the interactions in an online community, permeated by the symbolic dimension of the consumption of Ubuntu, is defined as an object of research, it is possible to say that the software is a sign that is socially shared. From this point of view, the meaning of Ubuntu is established or changed by its users/consumers to the extent that they use Ubuntu as a representation of the self (or selves) in their interactions in the Ubuntu community.

The community and texts used to build this research were chosen because of their introspective nature, determined by the knowledge a speaker that belongs to the community or culture has of the language adopted. An interpretative approach was used to expand the scope of the research, to better contemplate the contextual considerations available in the virtual community (TRAUTH and JESSUP, 2000). The study is conducted based on Wittgenstein's (2003) assumption (in his second philosophy) that community members should share the same "language game", understood here as the language between words and the world, in two ways, giving meaning to the relationship between reality and object, characterizing members' competencies to join that group. Thus, considering our goal of understanding certain cultural aspects of Ubuntu online 'speech community' through the interaction that occurs between members, and the understanding that they share the way how language signs are used, linguistically or not (GUMPERZ, 1972), the study adopts the netnography as the method to conduct the research (KOZINETS, 2002; JANSEN, SPINK and TAKSA, 2009; BOWLER, 2010).

The research also adopts the ethnography of communication (SAVILLE-TROIKE, 2003), based both in linguistics and in anthropology. The method considers communication as a means to make sense of the world, being an integral part of the culture (FARAH, 1997). Communication is constrained by culture, at the same time as it reveals and supports it (POLUKHINA and STRELNIKOVA, 2015). To access and interpret verbal and non-verbal language used in Ubuntu community interactions we used the protocol analysis proposed by Freitas and Leão (2012), called netnography of communication since it presents criteria developed for the ethnography of communication in an online context. It is presented in Box 1 below.

\section{Box 1}

\section{Protocol for data analysis}

\begin{tabular}{|c|c|c|}
\hline \multirow{6}{*}{ 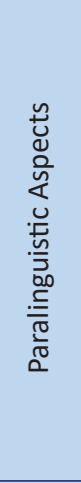 } & Accentuation & $\begin{array}{l}\text { It involves changes in how words are written with tonics accents, to reduce the number of characters } \\
\text { or symbols needed to form the word, according to norms. }\end{array}$ \\
\hline & Voice Height & Internet communication is characterized mainly by the capitalization of all the letters of the word (s). \\
\hline & $\begin{array}{l}\text { Length of } \\
\text { utterance }\end{array}$ & $\begin{array}{l}\text { It refers to the repetition of letters or use of suspension points in order to lengthen the pronunciation } \\
\text { of the word or phrase. }\end{array}$ \\
\hline & Intonation & $\begin{array}{l}\text { It is characterized by the use of exclamation marks, question marks, to demonstrate surprise, } \\
\text { doubt, and amazement. }\end{array}$ \\
\hline & Tone & $\begin{array}{l}\text { It refers to expressions that are not facial, related to voice, usually towards sighing, to opine, } \\
\text { bragging, for instance. }\end{array}$ \\
\hline & $\begin{array}{l}\text { Ortoepical } \\
\text { changes }\end{array}$ & $\begin{array}{l}\text { It refers to the changes in the spelling of words and expressions, aiming to reduce them in size } \\
\text { and to highlight accents. }\end{array}$ \\
\hline 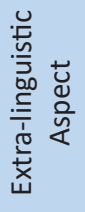 & $\begin{array}{l}\text { Facial } \\
\text { expression }\end{array}$ & $\begin{array}{l}\text { It is the written words and symbols in order to demonstrate facial expressions, such as laugh and } \\
\text { giggles, from the repetition of letters, or other uses of symbols in an unusual way, for example (: P). }\end{array}$ \\
\hline \multirow{4}{*}{ 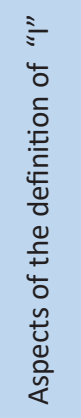 } & Deictic motion & $\begin{array}{l}\text { It refers to written expressions used to demonstrate specific gestures that indicate direction, for } \\
\text { example. }\end{array}$ \\
\hline & $\begin{array}{l}\text { Code } \\
\text { alternance }\end{array}$ & $\begin{array}{l}\text { It occurs when the written form of some word or the use of inverted commas on them changes } \\
\text { its usual meaning, including the replacement of words with numbers, for example, whose specific } \\
\text { use is understood by a cultural group or tribe. }\end{array}$ \\
\hline & $\begin{array}{l}\text { Knowledge } \\
\text { of the world }\end{array}$ & $\begin{array}{l}\text { It is characterized by the knowledge built by a group or by common sense, shown here from the } \\
\text { use of written words in a distinct way from dictated by norms or changing its usual meaning to } \\
\text { another shared by a group, culture or common sense. }\end{array}$ \\
\hline & Footing & $\begin{array}{l}\text { It occurs by the use of symbols or signs, for example, brackets that disassociate change in alignment } \\
\text { of the interactants. }\end{array}$ \\
\hline
\end{tabular}

Source: Freitas and Leão (2012). 
Symbolic consumption and representation of self: a study of interactions in a virtual community of Ubuntu-Br users
Osíris Luís da Cunha Fernandes | Nelson da Cruz Monteiro Fernandes Fernando Gomes de Paiva Júnior | André Luiz Maranhão de Souza Leão Marconi Freitas da Costa

The nethnographic survey was conducted over 12 months, between October 2011 and October 2012 and offered 89 observations. Data collection was done through the compilation of testimonies (LINCOLN and GUBA, 1985) taken from channel "space of ..." in the community forum, where viability and digital convenience did not require the use of recorder or notes during the collection, as advocated in the usual and ethnography procedures (KEATING, 2001). Data was managed by separating the statements according to the date of posting (according to the period established for the research), saving them in folders of virtual file with the titles of the testimonies, and sorting these statements with the letter " $D$ " and the date they were posted. Inside the folders of each testimony, the image of the computer screen was saved, named "T." Finally, member comments, named "C." Thus, during the data analysis, each part of the collection was analyzed under the D1T1C1 form, for example, the number following letters correspond to the number assigned to each highlighted statement (D), screen (T) and comment (C).

Observing an ethnographic condition of immersion in the Ubuntu community to validate the qualitative research, we join the community as observers, collecting data through non-participatory observation and following the community at a distance. Also, as criteria of validity and reliability of the data, we used the triangulation and the rich stealth, as recommend by Paiva Junior, Leão and Mello (2011). Also, we followed the recommendations offered by Alvesson and Skoldberg (2009) related to the reflectivity as a criterion of reliability (for before and after the event), which generates the researcher processing. Thus, reflexivity was a constant form of contriving limiting elements and potentially to restricting the quality of data and analysis.

For this research, aspects of reliability and validity were used to evaluate the quality of the qualitative study, even though these aspects were related to a positivist approach and more research-oriented terms (KLEIN and MYERS, 1999). However, according to Pozzebon (2004), some authors defend other criteria to evaluate the research quality, such as (a) conformability criterion, which refers to the degree to which research findings are determined by the respondents and the conditions of the inquiry, and not by the biases, motivations, interests or perspectives of the researcher (BRINK, 2009); (b) transferability, which refers to the obligation of researchers to present their findings in ways that allow readers to consider their transferability and where assessment of the relevance of the reported findings rests with the reader (ENGWARD and DAVIS, 2015); (c) plausibility, referring to the ability of the text to connect to the reader's worldview and it addresses the rhetorical strategies used to compose a text that positions the work as relevant to the concerns of the intended audience (SCHULTZE, 2000); (d) authenticity means being genuine to the field experience as a result of "being there" (GOLDEN-BIDDLE and LOCKE, 1993). Meeting this criterion assures that the researcher was there (ALVESSON and SKOLDBERG, 2009), and was genuine to the experience in writing up the account; and (e) reflexivity, which implies reflection on text production and language use and reveals a kind of awareness of the ambiguity of language (ALVESSON and SKOLDBERG, 2009).

\section{RESULTS}

The reflections based on the analysis of the corpus formed from the data collected in Ubuntu community allowed to establish the existence of three aspects related to the uses and functions of language that deserve mention since they provide possible answers to the central question of the study, which we will try to answer in the final considerations.

\section{Forging the representation of self through statements of migration from Windows to Ubuntu}

The statement of Windows operating system users about their migration to Ubuntu constitutes one of the ways of representation of self in virtual interactions present in the Ubuntu Community. These interactions use paralinguistic aspects and aspects of the definition of "I" as the goal to project, corroborate and uplift values associated with Ubuntu and the recognition of new users in the identitary community. The following example illustrates an interaction situation between beginners in the use of Ubuntu in which one of the participants says enthusiastically to the group: 
Symbolic consumption and representation of self: a study of interactions in a virtual community of Ubuntu-Br users
Osíris Luís da Cunha Fernandes | Nelson da Cruz Monteiro Fernandes Fernando Gomes de Paiva Júnior | André Luiz Maranhão de Souza Leão Marconi Freitas da Costa

[Ubunters, good morning, I hope everyone is having a nice Sunday!!

After a month (using) only in live-CD and two weeks utilizing only Ubuntu (Installed twice haha), I must say that it is been a week I do not see the other operating system that we are forced to use in any regular PC ( $\$ \$ 500$ or more "unnoticed").]

The example shows the situation of a person who recently migrated from Windows to Ubuntu Operating System. This migration is made clear by the use of aspects of the definition of "I" [Code alternance: 'live-CD'; PCs, R\$500; Footing: (2 installations rsrs) [(installed twice haha)], ( $R \$ 500++~ " u n n o t i c e d ")$ [R\$500 or more "unnoticed")]; knowledge of the world: live-CD, PCs], paralinguistic aspects (intonation: "!!") and extralinguistic aspects (facial expression: rsrs [haha]) in order to project themself in the Ubuntu community, showing that they know "the other operating system]" (Windows), but have opted for the Ubuntu and want to be recognized as a user of this system.

The user begins by demonstrating knowledge of the world, by calling other interactors of 'Ubunters],' which also constitutes an attempt to break the ice (enhanced by the courteous greeting, 'Good morning and I hope everyone is having a nice Sunday!!]') We understand that the use of intonation ("!!") at the end of the first sentence is a warning to other members, in order to be recognized as a cheerful/friendly and polite person (with use of the facial expression ' $r s r s$ [haha],' representing laughs/demonstration of joy).

The word "unnoticed]" between quotation marks (use: footing in this situation) can be understood as a criticism of Windows users who do not care about each other, but can also mean the demarcation of a consistent position with a typical Ubuntu user, which does not let people in distress at their mercy (or unnoticed).

Scholars like Ravasi and Rindova (2008) argue that the social meanings of products act in the dimension of people's desires and are related to seeking social differentiation. Conscious or unconsciously, consumers are taking their buying decisions inspired by their identity or identity they intend to project or communicate (WITT, 2010). In this sense, the consumption of Ubuntu Operating System can contribute to the valorization of a person in the community of users. Also, it contributes to change the users social status or even jeopardize their reputation (DEANS, THOMAS, DAUBE et al., 2016). Therefore, the attention while choosing such software becomes extremely important for the social relationships of individuals, becoming part of their daily lives.

Shang, Chen and Huang (2012) used the theories of symbolic consumption, representation of self and computer-mediated environment, to investigate why people buy decorative symbolic goods in the virtual world to decorate avatars. They show that people access these virtual symbolic elements to heed their values and social and emotional pressures. In the midst of their social interactions, these users buy virtual goods to please themselves and make friends by projecting a desirable image in order to get positive emotional responses from the others.

The assumption of migration to Ubuntu makes it become part of the identity of the individual who has adopted it, which has led us to a discussion of multiple selves and the potential for an individual to be changed through consumption (GECAS, 1982), the same way that the relationship between belonging to a particular group and consumption (FISHER, BOLAND JUNIOR and LYYTINEN, 2016). In our study, we found that Ubuntu users' behavior was expressed through many selves (friendly, polite, helper), which adapt to different social situations in which they operate. The users establish their representation through these selves.

Similarly, Min and Lee (2011) investigated the virtual representation of the self of 312 bloggers and observed the profile of users as heterogeneous individuals, which show selves that are transformed according to the existing dynamics between the user, the technology and the tasks to be performed in different social contexts of use. This occurs through the process of documentation of their everyday life where they express emotions, articulate ideas, and opinions. So, the blogosphere is a mediator and a rich control space from which users present themselves for themselves and alterity (GOFFMAN, 1990), through their posts that reflect who they are and what they think, like, and have. It should be noted that in the cyberspace there is the advantage of choosing which aspects of self to focus on, as demonstrated in the studies by Behm-Morawitz (2013).

In the example that follows, there is a statement on "eclaration of love: I love the Ubuntu project!]," in which at one point one of the inter-agents states: "Ubuntu has changed my life! It changed my way of seeing the world, it changed my ideology! Ideology I have one to help me to live!]" (D14T2C1). 
Symbolic consumption and representation of self: a study of interactions in a virtual community of Ubuntu-Br users
Osíris Luís da Cunha Fernandes | Nelson da Cruz Monteiro Fernandes Fernando Gomes de Paiva Júnior | André Luiz Maranhão de Souza Leão Marconi Freitas da Costa

This extract makes it clear that one of the inter-agents stopped using Windows Operating System and adopted Ubuntu and, therefore, they need to declare that they are part of the users' community, formed by people who share the same ideology (humanity with others). This is a meaning built into the Ubuntu Operating System to which the user wants to be associated, and it is quite noticeable that people's adherence to Ubuntu and all the values and principles associated with it, are adopted into their own lives. The declaration of migrating to Ubuntu is demonstrated by the use of paralinguistic aspects, by using '!' (intonation) at the end of sentences, and 'ideologyyyy' (length of utterance) in order to praise the symbolic values (SCHOUTEN, 1991) associated with Ubuntu and to corroborate the assumption of these values by other community members.

In the same statement, the inter-agents make a plea to supporters:

Do not forget to provide technical support to people if they have any problems. Help them, go to their house if necessary, do not leave them alone using the system and tell them "do it yourself". You have to help the person learn about the system, otherwise there is the risk the person will go back to using Windows and they will have a bad impression of Linux (rather than a good one)].

In this case, the use of aspects of the definition of "I" (footing) with the use of quotation marks in "yourself]" and the parentheses "(ao invés de boa [rather than a good one])," shows the definition of appropriate behavior (ROBINSON, 2007) according to Ubuntu users. They care about knowledge sharing, contrary to what happens to Windows users who leave each other alone to solve their problems individually.

Moreover, by stating, "you have to help the person learn about the system, otherwise there is the risk the person will go back to using Windows and they will have a bad impression on Linux (rather than a good one)]" the inter-agent corroborates the idea that migration to Ubuntu requires technical support and help from more experienced users. Thus, while declaring the migration to Ubuntu, one offers to give support in the users' community forum. Moreover, the user showed concern in protecting Ubuntu users, preserving their identity characteristic as a collaborating person, committed to sharing knowledge (KEDZIOR, ALLEN and SCHROEDER, 2016).

The next extract presents a situation of interaction between beginners in Ubuntu, where one of the inter-agent had just installed the Ubuntu Operating System and said: "ps: I have been using Ubuntu for 40 minutes and it is great (facial expression -smiling)". Here, the use of extralinguistic aspects (facial expression: interpreted as a big smile), paralinguistic aspects (ortoepic variation: ps:) and aspects of the definition of "I" (code alternance: 40 minutes; show) are used to praise the statement about the migration to Ubuntu, and to demonstrate satisfaction for the immersion of the new user/inter-agent in a new identitary community. Thus, the symbolic value of Ubuntu serves as a new opportunity for the representation of certain social values, linked to issues of social acceptance as advocated by Killoran (2012).

\section{The expression of feelings to Ubuntu as a form of representation of self}

The representation of the self in virtual interactions also happens through the expression of feelings (GRUBB and GRATHWOHL, 1967) to Ubuntu. In these situations, the paralinguistic, extralinguistic and definition of "I" aspects are used to characterize and to emphasize the features of Ubuntu, as well as to corroborate and to preserve the feelings of the users to this Operating System. The following extracts are elucidative of the use of these aspects. In the first situation of interaction, a community member says: "I love you Ubuntu! Only one thing: you can go around distributing CD's of Ubuntu, Kubuntu, Xubuntu" (D72T2C1).

The use of exclamation (!) after "I love you Ubuntu]" denotes use of paralinguistic aspects (intonation) to emphasize a symbolic aspect of the consumption of Ubuntu, expressed in the form of love. Thus, the use of aspects of the definition of "I" is shown in reference to the various distributions of that Operating System 'Ubuntu, Kubuntu, Xubuntu' (knowledge of the world in this situation) and the most used way of installation, via " $\mathrm{CD}$ " (code alternance in this situation). These aspects are used to emphasize the diversity of the Ubuntu distributions, as well as to support the feeling of the Operating System quality, and therefore the inter-agent strongly recommended, "distributing CD's." The various versions of Ubuntu are appointed and serve as mechanisms for the expression of an identity, whereby he nurtures a feeling of love. Moreover, it also shows that he is aware of what happens in the community and have mastered their linguistic codes.

In the following interaction situation, another inter-agent declares: “I'm having an affair with Ubuntu too... my girlfriend cannot find out about that... (facial expression: P:P" (D72T1C4). 
Symbolic consumption and representation of self: a study of interactions in a virtual community of Ubuntu-Br users
Osíris Luís da Cunha Fernandes | Nelson da Cruz Monteiro Fernandes Fernando Gomes de Paiva Júnior | André Luiz Maranhão de Souza Leão Marconi Freitas da Costa

In this case, extralinguistic aspects (facial expression: P:P, smirk followed by laughter) and paralinguistic aspects (length of utterance: "...") are used to corroborate the feeling nourished by Ubuntu (a hidden passion). Also, the user adopts a metaphor "I have an affair with Ubuntu..." to emphasize that besides the "girl" (ortoepic variation, used instead of girlfriend") he has another passion, Ubuntu. By saying "my girlfriend cannot find out abou that...]" the inter-agent reveals a concern to preserve his self (face) that is not recognized as a traitor in the community. However, the use of facial expression at the end of this sentence, conceived as smirk followed by laughter reveal a certain irony, while also emphasizing the metaphor of amorous entity.

Therefore, it is possible to say that Ubuntu is also consumed as an ideal system to search living and multiple experiences, able to fill the space between the inner and the outer, between users personal and public world (SHANG, CHEN and HUANG, 2012). So, consumers forge multiple identities for this software on which they protect themselves, while they internalize their meanings and values (LUNA-CORTES, 2017), making it part of themselves.

The expression of feelings on the web represents a natural consequence of the consumer experiences in the virtual world, as this world becomes part of what Belk (2013) calls an extension of self. Consequently, the feelings developed within this virtual universe become part of the rich collection of experiences that reflect the idea of who we are and what we think (CASALO, FLAVIAN and GUINALIU, 2010). When others recognize these feelings in the community, they reinforce their inclusion in the network and develop interactions with positive meanings (FISHER, BOLAND JUNIOR and LYYTINEN, 2016). This contributes, according to Solomon (1983), to the alignment of their subjective feelings with objective places they occupy in the social and cultural world feelings.

\section{Support in the virtual community forum as a way of representation of self}

Providing support in the Ubuntu communities' forum, especially to beginners in the use of Operating System Ubuntu, is a form of representation of self-used in virtual interactions. In this sense, the paralinguistic aspects (GUMPERZ, 1982) and aspects of the definition of "I" are used to get attention, to emphasize, to enhance and to suggest the need for support in the community forum.

The interaction situation below shows the response of a community member to a beginner's question in Ubuntu labors on how to proceed in the forum in case of doubt related to the use of the software. He says, "try to access the channel \#ubuntu-br that has lots of content and immediate support! "We never stop!"]" (D15T3C15).

The demonstration of community knowledge is visible since the respondent recommends "channel \#ubuntu-br". The use of exclamation at the end of the sentence "try to access the channel \#ubuntu-br that has lots of content and immediate support!" represents an intonation (paralinguistic aspect) (SAVILLE-TROIKE, 2003), given to the respondent speech to draw attention to himself and to the community in order to show that the community cares about sharing knowledge and providing technical support to its members, a fact that deserves to be highlighted.

On the other hand, intonation also has the function of emphasizing the responsiveness of the "immediate" support and makes clear that Ubuntu users will always find support/help in the forum of their community. Finally, the user writes: "We never stop!", where we also found the use of paralinguistic aspects (intonation: !) and aspects of the definition of "I" (footing, by the use of quotation marks " ") to suggest that the support in the forum is constant. This answer also sounds like an attempt to rescue the face, probably in order to preserve from possible questions about the delay or failure to respond to the community members' doubts (GUAN, WANG, JIN et al., 2018).

Individuals seek to buy objects that convey their lifestyle (LANIER JUNIOR and RADER, 2017) and make it clear to their peers their social position and their way of acting and seeing the world. Therefore, the use of Ubuntu may indicate that the person is modern, young, and knowledgeable about advances in the field of information and communication technology (ICT). Moreover, the significance of this software stems from its ability to act as an indicator of social status (WITT, 2010). Thus, the symbolic consumption of Ubuntu is a practice that drives the relationship between its users.

A similar result appears in the study of Manago, Graham, Greenfield et al. (2008) that explores how young people experience social networks within MySpace in the development of personal, social and gender identities. The authors identify that the peer-to-peer relationships among students suggest that they use MySpace to explore identities, compare themselves socially and express idealized aspects of self with which they identify. 
Symbolic consumption and representation of self: a study of interactions in a virtual community of Ubuntu-Br users
Osíris Luís da Cunha Fernandes | Nelson da Cruz Monteiro Fernandes Fernando Gomes de Paiva Júnior | André Luiz Maranhão de Souza Leão Marconi Freitas da Costa

In this sense, social networking websites provide good opportunities for young people to realize their various possible selves (LUNA-CORTES, 2017). These communities are facing new cultural tools for the construction of identities in their daily interactions. Therefore, it shows that users of Operating System studied transform ideas about the self in objectified images and these images aim to achieve public approval by their audiences.

In another interaction situation, another community member comments on the commitment of a fellow community by stating: "This guy does not manage to stay away, not even when sick and with "stitches," hehehe. This "Creed" (playing with the words "Creed," which is the name of the user that is sick and "Creed" an expression equivalent to "oh gosh")..." (D19T2C7).

In this situation, the use of extralinguistic and paralinguistic aspects (ERVIN-TRIPP, 1972) aimed at calling attention to a community member who was really sick but could not stay away from the community forum. "he guy" represented by a code alternance used to praise the commitment of a person with the support in the forum, also serves to emphasize its concern with community colleges. "Sewn" between quotation marks represent the footing aspect of the interaction in an attempt to show a different positioning of the person that even operated does not forget the others. This element shows a symbolic component associated with the use of Ubuntu, humanity with each other, showing that consumers /users of Ubuntu can sacrifice to help others in a difficult situation.

The facial expression (hehehehe), representing laughter, was used to enhance the attitude of the user through a demonstration of happiness/contentment. Here we see an individual whose self is aligned with the concept of self portrayed by Goffman, according to which the human is socially constructed by the otherness (GOFFMAN, 1990), i.e., the identity of the "face" that "(...) does not manage to stay away, not even when sick and with "stitches" (...)]" it amounts in the assumption of social role of the developer, whose primary goal is to know himself and others.

Finally, as signaled by Certeau (1984), people can create new meanings to previously established social situations (called by the author as "arts of making"), and the symbolic weight that products carry may be included in this field. Hence, by this logic, the social functions of products become central, with this shift of meaning created by the appropriation of what each individual does and that when it is recognized by peers, shall move the gears of social relations (NOBLE and WALKER, 1997). Therefore, decisions, intentions, and practices in the field of self, influence the general social life and are influenced by it in an interactive and able to build human life (HILSEN and HELVIK, 2014).

\section{CONCLUSION}

This study adopted interactional sociolinguistics (GOFFMAN, 1967) as a theoretical lens, and the netnography of communication (KEATING, 2001) as a method, because they congregate the functional nature of the discourse analysis carried out. This perspective focuses on the cultural aspects used during people's interaction (verbal and nonverbal) within a community.

We chose the functional approach of the discourse analysis due to our quest for understanding the representation of self in interactions in virtual communities through the symbolic consumption of Ubuntu free software. We used both the Goffman conception of self and Ravasi and Rindova's (2008) conception of symbolic consumption in order to contribute to an alternative vision to those presented in current research in the field of organizational studies.

People adapt their forms of communication to the Internet and strive to express most difficult nonverbal aspects to be featured from the context in face-to-face interactions, given its inherent cultural and sociolinguistic factors that push the boundaries of voice. Thus, for the analysis of the corpus formed with data collected in the Ubuntu virtual community from Brazil, we use the protocol for data analysis developed by Freitas and Leão (2012) as a means to access and interpret the verbal and nonverbal languages used in interactions at this virtual community. After the netnography, the research question: how does the representation of self in virtual interactions occur through the symbolic consumption of the Ubuntu Operating System? was addressed.

In its symbolic production developers bind to Ubuntu operating system's principles and cultural values, such as freedom (to change the source code, adapting the software to individual needs), the commitment to knowledge sharing, mainly through technical support in the forum of the identitary community of members, and the notion of humanity with each other. Thus, 
Symbolic consumption and representation of self: a study of interactions in a virtual community of Ubuntu-Br users
Osíris Luís da Cunha Fernandes | Nelson da Cruz Monteiro Fernandes Fernando Gomes de Paiva Júnior | André Luiz Maranhão de Souza Leão Marconi Freitas da Costa

we can infer that the principles of the Ubuntu are used in the dynamics for the representation of the self of its users, and are part of their socialization in the identitary communities.

In virtual interactions, Ubuntu is used as a sign that works with shared meanings that function in the representation of the self of the Ubuntu users in the virtual community. Thus, the lifestyle based on Ubuntu ideology was intensely flagged in the interactions observed. In many situations, the symbolic aspects appeared, for example, through the use of paralinguistic aspects such as intonation, either by using the statement or exclamation, praising the migration of users from Windows to Ubuntu, i.e., the adoption of a lifestyle based on the principles of Ubuntu. From this perspective, the perceived value of using Ubuntu is closely related to the symbolic elements associated with it, such as the commitment to sharing knowledge and humanity with the others.

Moreover, we note that when consumption is representative of the self, Ubuntu users use the symbolic resources associated with the operating system to project themselves in their identitary community, Ubuntu-Br, as happy, friendly, modern people and knowledgeable of the world of free software. So, Ubuntu is consumed more depending on the meanings embedded in it during its production, which make it an excellent sign for the interactions with the potential to allow the characterization of an identity, a culture (the self). We also verified that at different moments, the symbolic consumption of this software was associated with the shared understanding of users on the way of acting in Ubuntu-Br community characterizing the sharing of ideals, values, and principles as dominant factors for admission and permanence in the Ubuntu-Br virtual community.

The study supports the hypothesis that, in the consumption operating systems of open code, the ownership over customization is used for the representation of the self in virtual communities. As the main conclusions of this study, we identified three main forms of representation of the self in virtual interactions through the symbolic consumption of the free software Ubuntu: 1) Statement of migration from Windows to Ubuntu - the symbolic resources tied to the open code operating system permits the statement of migration from Windows to Ubuntu operating system to be used as a form of self-representation in the Ubuntu-Br community through the use of paralinguistic aspects and aspects of the definition of "I" aiming to project, corroborate and praise the values assigned to Ubuntu and the recognition of new members in the identity community of users of this software; 2) Expression of feelings to Ubuntu- mainly through the use of extralinguistic and the definition of "I" aspects to characterize and emphasize the characteristics of Ubuntu as well as to support and preserve the feelings of the users to this software; 3) Providing technical support in the forum of the virtual community - through the use of paralinguistic aspects and aspects of the definition of "I", to draw attention, emphasize, praise and suggest the provision of technical support in the forum by one of the community members.

Finally, these representations of 'self' allow users of free software to project the desired self-image in interactions in virtual communities. The forms of representation of 'self' inferred in this study do not exhaust all possibilities. Instead, they open space for a managerial use, as a new option for symbolic production of software (free and proprietary), considering the capacity of symbolic components linked to them becoming part of the identity/self of users. Thus, one of the implications we can glean from this study is that self-representative consumption of open code operating systems play a key role in the construction of the self in terms that go beyond the consumption of material goods in the offline world, especially because the symbolic resources associated to free software are used as elements of differentiation from proprietary closed systems users. 
Symbolic consumption and representation of self: a study of interactions in a virtual community of Ubuntu-Br users
Osíris Luís da Cunha Fernandes | Nelson da Cruz Monteiro Fernandes Fernando Gomes de Paiva Júnior | André Luiz Maranhão de Souza Leão Marconi Freitas da Costa

\section{REFERENCES}

ALMEIDA, S. O. et al. Efeitos da comunidade de origem no participante de comunidades virtuais de marca. RAE-Revista de Administração de Empresas, v. 52, n. 2, p. 204-216, 2012.

ALVESSON, M.; SKOLDBERG, K. Reflexive methodology: new vistas for qualitative research. 2. ed. London: SAGE Publications, 2009.

BAUMHAMMER, P.; SILVA, M. G.; COSTA, M. F. Aspectos simbólicos do smartphone e o eu estendido: um estudo do comportamento do consumidor português. Revista Interdisciplinar de Marketing, v. 7. n. 2, p. 175-190, 2017.

BELK, R. W. Extended self in a digital world. Journal of Consumer Research, v. 40, n. 3, p. 477-500, 2013.

BEHM-MORAWITZ, E. Mirrored selves: The influence of self-presence in a virtual world on health, appearance, and well-being. Computers in Human Behavior, v. 29, n. 1, p. 119-128, 2013.

BLUMER, H. Symbolic interactionism: perspective and method. 6. ed. Berkeley: California University Press, 1986.

BRINK, M. A. Rijkswaterstaat on the horns of a dilemma. Delft: Eburon, 2009.

BOWLER, G. M. Netnography: A method specifically designed to study cultures and communities online. The Qualitative Report, v. 15 , n. 5 , p. $1270-1275,2010$.

CASALO, L. V.; FLAVIAN, C.; GUINALIU, M. Relationshipquality, communitypromotion and brandloyalty in virtual communities: evidencefromfree software communities. International Journal of Information Management, v. 39, n. 4, p. 357-367, 2010.

CASTELLS, M. The internet galaxy: Reflections on the internet, business, and society. Oxford: Oxford University Press, 2002.

CASTELLS, M. The rise of the network society. 2. ed. West Sussex: The John Wiley \& Sons, 2010.

CERTEAU, M. The practice of every Day life. Berkeley: University of California Press, 1984.

CHANG, K. W.; LI, S. Y. Understanding consumer-to-consumer interactions in virtual communities: the salience of reciprocity. Journal of Business Research, v. 63, n. 9, p. 1033-1040, 2010.

COMOR, E. Contextualizing and critiquing the fantastic prosumer: Power, alienation and hegemony. Critical Sociology, v. 37, n. 3, 2010. 309-327 p.

DEANS, E., et al. Creating symbolic cultures of consumption: ananalys is of the content of sports wagering advertisements in Australia. BMC Public Health, v. 16, n. 208, p. 1-11, 2016.

DIONYSIOU, D. D.; TSOUKAS. H. Understandingthe (re)creation of routines from within: A symbolic interactionist perspective. Academy of Management Review, v. 38, n. 2, p. 181-205, 2013.

EKINCI, Y.; SIRAKAYA-TURK, E.; PRECIADO, S. Symbolic consumption of tourism destination brands. Journal of Business Research, v. 66, n. 6, p. 711-718, 2013.

ENGWARD, H.; DAVIS, G. Being reflexive in qualitative grounded theory: discussion and application of a model of reflexivity. Journal of Advanced Nursing, v. 71, n. 7, p. 1530-1538, 2015.
ERVIN-TRIPP, S. On sociolinguistic rules: Alternation and co-occurrence. In: GUMPERZ, J.; HYMES, D. (Eds.). Directions in sociolinguistics: the ethnography of communication. Basil Blackwell: New York, 1972.

FARAH, I. Ethnographyof communication. In: HORNBERGER, N. H.; CORSON, D. (Eds.). Encyclopedia of language and education. Dordrecht: Springer, 1997.

FISHER, M.; BOLAND JUNIOR., R.; LYYTINEN, K. Social networking as theproduction and consumption of a self. Information and Organization, v. 26, n. 4 , p. 131-145, 2016.

FONSECA, M. J. et al. Tendências sobre as comunidades virtuais da perspectiva dos prosumers. RAE Electrônica, São Paulo, v. 7, n. 2, July/Dec. 2008. Available at: <http://dx.doi.org/10.1590/S167656482008000200008>. Accessed on: Sept. 09, 2019.

FREITAS, G. K.; LEÃO, A. L. M. de S. A elaboração da face em comunidades virtuais de marca: um estudo de caso sobre uma comunidade virtual de consumidores da Coca-Cola. Cadernos EBAPE.BR, Rio de Janeiro, v. 10, n. 1, p. 181-201, 2012.

GBADAMOSI, A. Brand personification and symbolic consumption among ethnic minority teenage consumers: an empirical study. Journal of Brand Management, v. 22, n. 9, p. 737-754, 2015.

GECAS, V. The self-concept. Annual Review of Sociology, v. 8, p. 1-33, 1982.

GOLDEN-BIDDLE, K.; LOCKE, K. Appealing work: An investigation of how ethnographic texts convince. Organization Science, v. 4, n. 4, p. 595-616, 1993.

GOFFMAN, E. Interaction ritual: essays on face-to-face behavior. New York: Anchor, 1967.

GOFFMAN, E. Frame analysis: an essay on the organization of experience. New York: Harper and Row, 1974.

GOFFMAN, E. The presentation of self in evey Day life. London: Penguin, 1990.

GRUBB, E. L.; GRATHWOHL, H. L. Consumer self-concept, symbolism and market behavior: a theoretical approach. Journal of Marketing, v. 31, n. 4, p. 22-27, 1967.

GUAN, T. et al. Knowledge contribution behavior in online Q\&A communities: an empirical investigation. Computers in Human Behavior, v. 81, p. 137-147, 2018.

GUMPERZ, J. Sociolinguistics and communication in small groups. In: PRIDE, J. B.; HOLMES, J. (Eds.). Sociolinguistics. Penguin: Harmondsworth, Middlesex, 1972.

GUMPERZ, J.; HYMES, D. Directions in sociolinguistics: the ethnography of communication. Basil Blackwell: New York, 1972.

GUMPERZ, J. J. Discourse strategies. Cambridge: Cambridge University Press, 1982.

GUMPERZ, J. J. On interactional sociolinguistic method. In: SARANGI, S.; ROBERT, C. (Eds.). Talk, work and institutional order: discourse in medical, mediation and management settings. New York: Mouton de Gruyter, 1999. 
Symbolic consumption and representation of self: a study of interactions in a virtual community of Ubuntu-Br users
Osíris Luís da Cunha Fernandes | Nelson da Cruz Monteiro Fernandes Fernando Gomes de Paiva Júnior | André Luiz Maranhão de Souza Leão Marconi Freitas da Costa
HABERMAS, J. Pensamento pós-metafísico: estudos filosóficos. 2. ed. Rio de Janeiro: Tempo Brasileiro, 2002.

HABIBI, M. R.; LAROCHE, M.; RICHARD, M. O. Testing an extended model of consumer behavior in the context of social media-based brand communities. Computers in Human Behavior, v. 62, p. 292302, 2016.

HAMARI, J.; KERONEN, L. Why do people buy virtual goods: a metaanalysis. Computers in Human Behavior, v. 71, p. 59-69, 2017.

HAMMERL, M. et al. Attribution of symbolic brand meaning: The interplay of consumers, brands and reference groups. Journal of Consumer Marketing, v. 33, n. 1, p. 32-40, 2016.

HARMON-KIZER, T. R. et al. When multiple identities compete: The role of centrality in self-brand connections. Journalof Consumer Behavior, v. 12, n. 6, p. 483-495, 2013.

HILSEN, A. I.; HELVIK, T. The construction of self in social medias, such as Facebook. Al \& Society, v. 29, n. 1, p. 3-10, 2014.

HILL, B. M.; BACON, J.O livro oficial do Ubuntu. Porto Alegre: Bookman, 2008.

HIMANEN, P. The hacker ethic and the spirit of capitalism. New York: Random House, 2001.

JANSEN, B.J.; SPINK, A.; TAKSA, I. Handbook of research on web log analysis. Hersey: IGI Global, 2009.

KEATING, E. The ethnography of communication. In: ATKINSON, P. et al. (Eds.). Handbook of ethnography. London: SAGE, 2001.

KEDZIOR, R.; ALLEN, D. E.; SCHROEDER, J. The selfie phenomenon: consumer identities in the social media marketplace. European Journalof Marketing, v. 50, n. 9, p. 1767-1772, 2016.

KILLORAN, J. B. Is it "about us"? Self-representation of technical communication consultants, independent contractors, and companies on the web. Technical Communication, v. 59, n. 4, p. 267-285, 2012.

KLEIN, H. K.; MYERS, M. D. A set of principles for conducting and evaluating interpretive field studies in information systems. MIS Quarterly, v. 23, n. 1, p. 67-94, 1999.

KOTARBA, J. A. Symbolic interaction and applied social research: a focus on translational science. Symbolic Interaction, v. 37, n. 3, p. 412-425, 2014.

KOZINETS, R. V. The field behind the screen: Using netnography for marketing research in online communities. Journal of Marketing Research, v. 39, n. 1, p. 61-72, 2002.

LANIER JUNIOR, C. D.; RADER, C. S. Deconstructing symbolic consumption: exploring the anti-synthetic space between meaning and meaninglessness. Consumption Markets \& Culture, v.20, n. 3, p. $215-244,2017$.

LESSIG, L. Cultura Livre: como a grande mídia usa a tecnologia e a lei para bloquear a cultura e controlar a criatividade. São Paulo: Trama, 2005.

LINCOLN, Y. S.; GUBA, E. G. Naturalistic inquiry. London: SAGE Publications, 1985.

LOWE, R.; POW, N.; SERBAN, I. V.; CHARLIN, L.; LIU, C. W.; PINEAU, J. Training end-to-end dialogue systems with the Ubuntu dialogue corpus. Dialogue \& Discourse, v. 8, n. 1, p. 31-65, 2017.
LUNA-CORTES, G. The influence of symbolic consumption on experience value and the use of virtual social networks. Spanish Journal of Marketing - ESIC, v. 21, n. 1, p. 39-51, 2017.

MANAGO, A. M. et al. Self-presentation and gender on MySpace. Journal of Applied Developmental Psychology, v. 29, n. 6, p. 446-458, 2008. Available at: <https://doi.org/10.1016/j.appdev.2008.07.001>. Accessed on: Sept. 09, 2019.

MEAD, G. H. Mind, self, and society. Chicago: The University of Chicago Press, 2015.

MCCAHILL, M.The surveillance web: the rise of visual surveillance in an English city. Cullompton: Willan Pub, 2002.

MCCRACKEN, G. Culture and consumption: new approaches to the symbolic character of consumer goods and activities. Bloomington: Indiana University Press, 1990.

MIN, J.; LEE, H. The change in user and IT dynamics: blogs as IT-enabled virtual self-presentation. Computers in Human Behavior, v. 27, n. 6, p. 2339-2351, 2011.

MORGAN, G. Transnational communities and business systems. Global Networks, v. 1, n. 2, p. 113-130, 2011.

MUELLER, F. Taking Goffman seriously: developing strategy-aspractice. Critical Perspectives on Accounting, v. 53, p. 16-30, 2018.

NOBLE, C. H.; WALKER, B. A. Exploring the relationship among liminal transitions, symbolic consumption, and the extended self. Psychology \& Marketing, v. 14, n. 1, p. 29-47, 1997.

PAIVA JUNIOR, F. G.; LEÃO, A. L. M. S.; MELLO, S. C. B. Validade e confiabilidade na pesquisa qualitativa em Administração. Revista de Ciências da Administração, v. 13, n. 31, p. 190-209, 2011.

POLUKHINA, E.; STRELNIKOVA, A. Exploring the Russian online giftexchange communities: the results of nethnographic approach. The Qualitative Report, v. 20, n. 12, p. 2041-2049, 2015.

POZZEBON, M. Conducting and evaluating critical interpretive research: Examining criteria as a key component in building a research tradition. In: KAPLAN, B. et al. (Eds.) Information systems research: relevant theory and informed practice. Springer, Boston: Springer, 2004.

PRONAY, S.; HETESI, E. Symbolic consumption in the case of brand comunications. Society and Economy, v. 38, n. 1, p. 87-102, 2016.

RAVASI, D. RINDOVA, V. Symbolic value creation. In: BARRY, D.; HANSEN, $\mathrm{H}$. (Eds.). The sage handbook of new approaches in management and organization. London: Sage, 2008.

RITZER, G.; JUGERSON, N. Production, consumption, prosumption: The nature of capitalism in the age of the digital 'prosumer'. Journal of Consumer Culture, v. 10, n. 1, p. 13-36, 2010.

RITZER, G. Prosumption: Evolution, revolution, or eternal return of the same? Journal of Consumer Culture, v. 14, n. 1, p. 3-25, 2014.

RITZER, G. Prosumer capitalism. The Sociological Quartely, v. 56, p. 413-445, 2015.

ROBINSON, L. The cyberself: the self-ing Project goes online, symbolic interaction in the digital age. New Media \& Society, v. 9, n. 1, p. 93-110, 2007.

SAVILLE-TROIKE, M. The ethnography of communication: an introduction. Malden: Blackwell Pub, 2003. 
Symbolic consumption and representation of self: a study of interactions in a virtual community of Ubuntu-Br users
Osíris Luís da Cunha Fernandes | Nelson da Cruz Monteiro Fernandes Fernando Gomes de Paiva Júnior | André Luiz Maranhão de Souza Leão Marconi Freitas da Costa
SCHAU, H.; GILLY, M. We are what we post? Self-presentation in personal web space. Journal of Consumer Research, v. 30, p. 285404, 2003.

SCHOUTEN, J. M. Selves in transition: symbolic consumption in personal rites os passage and identity reconstruction. Journal of Consumer Research, v. 17, n. 4, p. 412-425, 1991.

SCHULTZE, U. A confessional account of an ethnography about knowledge work. MIS Quarterly, v. 24, n. 1, p. 3-41, 2000.

SHANG, R. A.; CHEN, Y. C.; HUANG, S. C. A private versus a public space: anonymity and buying decorative symbolic goods for avatars in a virtual world. Computers in Human Behavior, v. 28, n. 6, p. 2227-2235, 2012.

SILVEIRA, S. A. Software livre: a luta pela liberdade do conhecimento. São Paulo: Fundação Perseu Abramo, 2004.

SODERBERG, J. Hacking capitalism: The free and open source software movement. New York: Routledge, 2012.

SOLOMON, M. R. The role of products as social stimuli: a symbolic interactionism perspective. Journal of Consumer Research, v. 10, n. 3, p. 319-329, 1983
STALLMAN, R. Free software, free society: selected essays of Richard M. Stallman. Boston: GNU Press, 2002.

TANGSUPWATTANA, W.; LIU, X. Symbolic consumption and Generation $Y$ consumers: evidence from Thailand. Asia Pacific Journalof Marketing and Logistics, v. 29, n. 5, p. 917-932, 2017.

TRAUTH, E. M.; JESSUP, L. M. Understanding computer-mediated discussions: Positivist and interpretive analyses of group support system use. MIS Quarterly, v. 24, n. 1, p. 43-79, 2000.

VAN DIJCK, J. The culture of connectivity: a critical history of social media. New York: Oxford University Press, 2013.

VELLOZO, H. S. Ubuntu e a Popularização do Software-Livre. In: Anais do Congresso Nacional Universidade, EAD e Software Livre. Belo Horizonte, 2012, Belo Horizonte. Anais... Belo Horizonte: UFMG, 2012.

WITT, U. Symbolic consumption and the social construction of product characteristics. Structural Change and Economic Dynamics, v. 21, n. 1, p. 17-25, 2010.

WITTGENSTEIN, L. Philosophische Untersuchungen. Frankfurt: Suhrkamp Verlag, 2003.

Osíris Luís da Cunha Fernandes

ORCID: https://orcid.org/0000-0003-4158-6995

PhD in Business Administration from the Federal University of Pernambuco (UFPE); Marketing and Operations Director of the Pernambuco Institute of Technology (ITEP), Recife- PE, Brazil. E-mail: osiriscunha@gmail.com

Nelson da Cruz Monteiro Fernandes

ORCID: https://orcid.org/0000-0002-1662-9300

PhD in Business Administration from the Federal University of Pernambuco (UFPE); Associate Professor at the Federal University of Pernambuco

(UFPE), Caruaru-PE, Brazil. E-mail: cruzfernandes55@gmail.com

Fernando Gomes de Paiva Júnior

ORCID: https://orcid.org/0000-0001-5715-3882

PhD in Business Administration from the Federal University of Minas Gerais (UFMG); Associate Professor at the Federal University of Pernambuco

(UFPE), Recife- PE, Brazil. E-mail: fernando.paivajr@pq.cnpq.br

André Luiz Maranhão de Souza Leão

ORCID: https://orcid.org/0000-0002-7660-5845

PhD in Business Administration from the Federal University of Pernambuco (UFPE); Associate Professor at the Federal University of Pernambuco (UFPE), Recife- PE, Brazil. E-mail: aleao21@hotmail.com

Marconi Freitas da Costa

ORCID: https://orcid.org/0000-0001-9888-8359

PhD in Business Administration from the University of São Paulo (FEA USP); Associate Professor at the Federal University of Pernambuco (UFPE), Caruaru-PE, Brazil. E-mail: marconi.fcosta@ufpe.br 